\title{
Corticotropin-Releasing Factor and Urocortin I Modulate Excitatory Glutamatergic Synaptic Transmission
}

\author{
Jie Liu, ${ }^{1}$ Baojian Yu, ${ }^{1}$ Volker Neugebauer, ${ }^{1}$ Dimitri E. Grigoriadis, ${ }^{2}$ Jean Rivier, ${ }^{3}$ Wylie W. Vale ${ }^{3}$ \\ Patricia Shinnick-Gallagher, ${ }^{1}$ and Joel P. Gallagher ${ }^{1}$ \\ ${ }^{1}$ Department of Pharmacology and Toxicology, University of Texas Medical Branch, Galveston, Texas 77555-1031, 2Neurocrine Biosciences Incorporated, \\ San Diego, California 92121, and ${ }^{3}$ Clayton Foundation Laboratories for Peptide Biology, The Salk Institute for Biological Studies, Peptide Biology \\ Laboratory, La Jolla, California 92037
}

Corticotropin-releasing factor (CRF)-related peptides serve as hormones and neuromodulators of the stress response and play a role in affective disorders. These peptides are known to alter complex behaviors and neuronal properties, but their receptor-mediated effects at CNS synapses are not well described. Here we show that excitatory glutamatergic transmission is modulated by two endogenous CRFrelated peptide ligands, corticotropin-releasing factor [CRF rat/human ( $\mathrm{r} / \mathrm{h})$ ] and Urocortin I (Ucn I), within the central nucleus of the amygdala (CeA) and the lateral septum mediolateral nucleus (LSMLN). These limbic nuclei are reciprocally innervated, are involved in stress and affective disorders, and have high densities of the $\mathrm{CRF}$ receptors $\mathrm{CRF}_{1}$ and $\mathrm{CRF}_{2}$. Activation of these receptors exerts diametrically opposed actions on glutamatergic transmission in these nuclei. In the $\mathrm{CeA}, \mathrm{CRF}(\mathrm{r} / \mathrm{h})$ depressed excitatory glutamatergic transmission through a $\mathrm{CRF}_{1}$-mediated postsynaptic action, whereas Ucn I facilitated synaptic responses through presynaptic and postsynaptic $\mathrm{CRF}_{2}$-mediated mechanisms. Conversely, in the LSMLN, CRF caused a CRF $\mathrm{F}_{1}$-mediated facilitation of glutamatergic transmission via postsynaptic mechanisms, whereas Ucn I depressed EPSCs by postsynaptic and presynaptic $\mathrm{CRF}_{2}$-mediated actions. Furthermore, antagonists of these receptors also affected glutamatergic neurotransmission, indicating that endogenous ligands tonically modulated synoptic activity at these synapses.

These data show that CRF receptors in CeA and LSMLN synapses exert and maintain a significant synaptic tone and thereby regulate excitatory glutamatergic transmission. The results also suggest that CRF receptors may provide novel targets in affective disorders and stress.

Key words: CRF; amygdala; lateral septum; glutamatergic synaptic transmission; synaptic homeostasis; urocortin

\section{Introduction}

Corticotropin-releasing factor (CRF), a 41 amino acid peptide purified and characterized initially by Vale et al. (1981), plays a major role in coordinating endocrine, autonomic, and behavioral responses to stress (Vale et al., 1981; Dunn and Berridge, 1990; Bale and Vale, 2004). CRF and its peptide family ("CRFrelated peptides") are also implicated in the pathophysiology of affective disorders (Steckler and Holsboer, 1999) such as anxiety and depression. Several known mammalian [CRF, Urocortin I (Ucn I), Ucn II, and Ucn III (these latter two having human homologs identified as stresscopin-related peptide and stresscopin, respectively; (Hsu and Hsueh, 2001)], and nonmammalian peptides are members of this family (Dautzenberg and Hauger, 2002). CRF-related peptide actions are mediated

Received July 18, 2003; revised March 10, 2004; accepted March 10, 2004.

This work was supported by National Institute on Drug Abuse Grants DA 11991 (J.P.G., P.S.-G.) and T32-A07287 (K.A.C.), National Institute of Mental Health Grant MH058327 (P.S.-G.), and a grant from the National Institute of Diabetes and Digestive and Kidney Diseases (W.W.V., J.R.). We thank Geoffrey Swanson, Kenneth Johnson, Kathryn Cunningham, and Paul Sawchenko for discussions and input.

Correspondence should be addressed to Dr. Joel P. Gallagher, University of Texas Medical Branch, Department of Pharmacology and Toxicology, 300 University Avenue, Galveston, TX 77555-1031. E-mail: jpgallag@utmb.edu. DOI:10.1523/JNEUROSCI.5531-03.2004

Copyright $\odot 2004$ Society for Neuroscience $\quad$ 0270-6474/04/244020-10\$15.00/0 through two different G-protein-coupled receptors (GPCRs), $\mathrm{CRF}_{1}$ and $\mathrm{CRF}_{2}$ (Hauger et al., 2003), and are associated with multiple signaling pathways (Grammatopoulos et al., 2001; Blank et al., 2003).

CRF-related peptides serve as hormones and regulators of pituitary function within the hypothalamic pituitary axis (HPA) but also are synthesized and released in specific brain areas outside the HPA (Swanson et al., 1983). Müller et al. (2003) demonstrated a non-HPA role for these peptides and their receptors in anxiety and stress using conditional $\mathrm{CRF}_{1}$-receptor knock-out animals. CRF-related peptides also regulate various behaviors as neurotransmitters or neuromodulators (Valentino, 1989; Owens and Nemeroff, 1993) outside the HPA; however, the roles of these peptides and their receptors in CNS synaptic transmission have not been thoroughly investigated.

The central nucleus of the amygdala $(\mathrm{CeA})$ and lateral septum mediolateral nucleus (LSMLN) are two limbic nuclei exhibiting high densities for $\mathrm{CRF}_{1}$ and $\mathrm{CRF}_{2}$, respectively (Chalmers et al., 1995; Li et al., 2002). The CeA, a major output nucleus of the amygdala complex, plays an essential role in anxiety, memory, stress, schizophrenia, and emotional reward circuitry (Aggleton, 1992; Shinnick-Gallagher et al., 2003). Similar to the CeA, the lateral septum is implicated in various normal and abnormal 
AMYGDALA
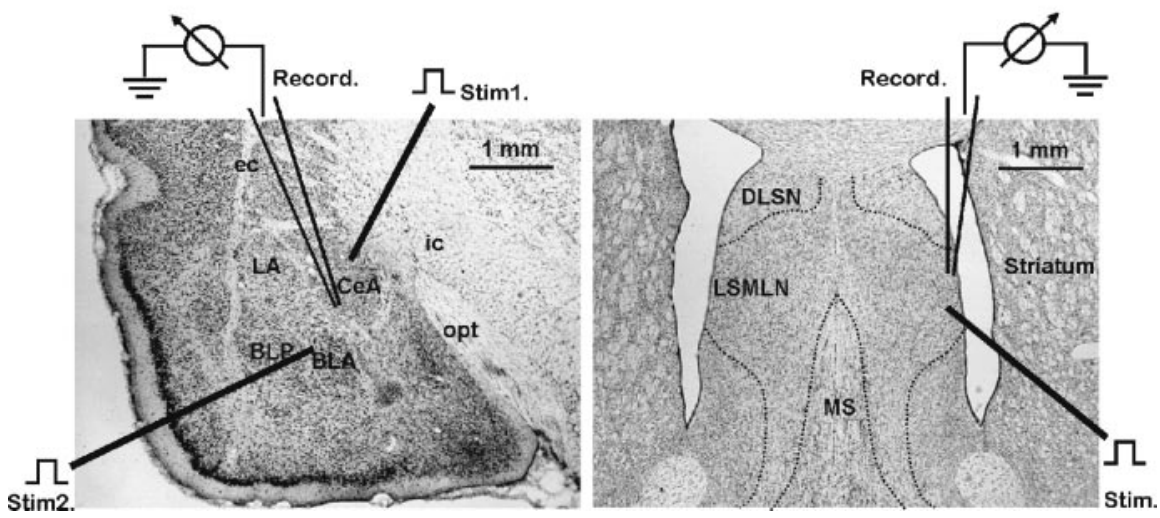

Figure 1. Illustration of brain slices containing the amygdala (left) and septum (right) showing recording and stimulation sites. Slices $(30 \mu \mathrm{m})$ were stained with cresyl violet and with drawing applied to denote positioning of stimulating and recording electrodes. Single recording electrode is shown within the $C e A$, with stimulating electrode 1 positioned to activate the VAP-CeA pathway and electrode 2 positioned to activate the BLA-CeA pathway. CeA, Central amygdala nucleus; LA, lateral amygdala nucleus; BLA, basolateral anterior amygdala nucleus; VAP, ventral amygdala pathway; BLP, basolateral posterior amygdala nucleus; ec, external capsule; ic, internal capsule; opt, optic tract. Single stimulating electrode is shown within the ventral LSMLN with the recording electrode positioned in the LSMLN. LSMLN, Lateral septum mediolateral nucleus; MS, medial septum; DLSN, dorsolateral septal nucleus.

behaviors, including fear, memory, food and water intake, anxiety, emotions, reward and addiction, schizophrenia, and stress (Numan, 2000). These two limbic nuclei comprise a direct and reciprocal neuronal circuit (Jakab and Leranth, 1995) involved in fear, stress, reward, and emotionality.

CRF influences neuronal properties. The slow afterhyperpolarizing potential (Aldenhoff et al., 1983; Rainnie et al., 1992; Fox and Gruol, 1993; Smith and Dudek, 1994) is inhibited by CRF, an effect that would augment excitability. CRF also enhances R-type voltage-gated calcium channels in rat $\mathrm{CeA}$ neurons ( $\mathrm{Yu}$ and Shinnick-Gallagher, 1998), suggesting a role in neurotransmission. Furthermore, excitatory glutamatergic transmission is potentiated via a $\mathrm{CRF}_{2}$ modulation of NMDA transmission; this effect is dependent on CRF-binding protein in mouse ventral tegmental neurons (Ungless et al., 2003). Multiple studies also implicate a role for CRF in long-term potentiation (Wang et al., 2000; Bishop, 2002; Blank et al., 2002) and long-term depression (Miyata et al., 1999) and suggest that different intracellular signaling pathways may be responsible for the long-term effects.

The purpose of this study was to use selective pharmacological probes to determine the functional roles of CRF-related peptides at glutamatergic synapses of limbic nuclei known to express $\mathrm{CRF}_{1}$ and $\mathrm{CRF}_{2}$ receptors.

\section{Materials and Methods}

Animals and tissue collection. Brain slices containing the CeA or LSMLN were prepared from the same animals. Male rats (Sprague Dawley, 100250 gm; Harlan, Indianapolis, IN) were used to examine the actions of CRF-related peptides on individual neurons while monitoring evoked EPSCs and miniature EPSCs (mEPSCs) in the CeA and lateral LSMLN (Neugebauer et al., 2000; Yu et al., 2002). Rats were decapitated and the brain rapidly removed and immersed in a cold $\left(\sim 5^{\circ} \mathrm{C}\right)$ artificial CSF (ACSF) solution that was bubbled continuously with $95 \% \mathrm{O}_{2} / 5 \% \mathrm{CO}_{2}$ to maintain proper $\mathrm{pH}$ (7.3-7.4). The composition of this control ACSF is (in mM): $117 \mathrm{NaCl}, 3.5 \mathrm{KCl}, 1.2 \mathrm{NaH}_{2} \mathrm{PO}_{4}, 2.5 \mathrm{CaCl}_{2}, 25 \mathrm{NaHCO}_{3}$, and 11.5 glucose. To generate septal slices, an isolated brain was quickly blocked initially to transverse sections $\sim 5 \mathrm{~mm}$ thick, with the caudal edge at the level of the optic chiasm. A second 5-mm-thick block of tissue was cut from the more caudal aspect of the same brain to generate brain slices containing the amygdaloid complex. Each frontal and caudal 5 mm block of tissue was then glued to the specimen holder in a Vibroslice chamber, and individual $500-\mu \mathrm{m}$-thick slices containing the appropriate nuclei from the same rat were sectioned (Fig. 1) and transferred to individual recording chambers maintained at $32 \pm 2^{\circ} \mathrm{C}$.

Whole-cell patch-clamp recording. Whole-cell recordings were obtained from either the amygdala (Neugebauer et al., 2000) or septal (Yu et al., 2002) slice preparations. Patch electrodes had tip resistances of 3-5 $\mathrm{M} \Omega$ when filled with an internal solution containing (in $\mathrm{mM}$ ): 122 K-gluconate, $5 \mathrm{NaCl}, 0.3 \mathrm{CaCl}_{2}, 2 \mathrm{MgCl}_{2}, 1$ EGTA, 10 HEPES, $5 \mathrm{Na}_{2}$-ATP, $0.4 \mathrm{Na}_{3}$-GTP adjusted to $\mathrm{pH} 7.2-7.3$ with $\mathrm{KOH}$ and to osmolarity of $280 \mathrm{mmol} / \mathrm{kg}$ with sucrose.

Evoked EPSCs and mEPSCs. Afferent inputs to the respective nuclei were stimulated via a bipolar stimulating electrode (SNE-100, Kopf Instruments) placed in ventral amygdala (VAP) (Fig. 1, left top, Stim 1) and the basolateral amygdala (BLA) (Fig. 1, left, Stim 2) pathways while we recorded from the lateral capsular region of the $\mathrm{CeA}$, and in the ipsilateral ventral aspect of the LSMLN while we recorded from the LSMLN (Fig. 1, right, Stim). Stimulus parameters were adjusted to yield consistent responses, e.g., $150 \mu \mathrm{sec}$ duration and $1-25 \mathrm{~V}$ intensity at a frequency of $0.1-0.25 \mathrm{~Hz}$. For evaluation of drug effects on EPSCs, stimulus intensities were adjusted to one-half of threshold for orthodromic spike generation. In all experiments in which EPSC data were reported, brain slices were superfused with a mixture of picrotoxin, bicuculline methiodide, and CGP55845 added to the normal ACSF. In the paired-pulse paradigm, the first response (EPSC1) and the second, or test, response (EPSC2) were elicited in septal afferents at intervals of 35-200 msec. The amplitude of the tail of the first EPSC at the initiation of the second EPSC was subtracted, and the ratio of facilitation was calculated according to the following formula: (EPSC2/EPSC1). The ratio of facilitation was plotted as a function of the interstimulus interval for control brain slices and after treatment with CRF-related peptides. Evoked currents were acquired and analyzed using pClamp, version 9.1 software. Measurements were collected with an Axoclamp-2A amplifier at a switching frequency of $5-6 \mathrm{kHz}(30 \%$ duty cycle), gain of $3-8 \mathrm{nA} /$ $\mathrm{mV}$, and time constant of $20 \mathrm{msec}$. Phase shift and anti-alias filter were optimized. Headstage voltage was monitored on a separate oscilloscope to ensure optimum performance of the amplifier.

mEPSC activity was analyzed off-line using Synaptosoft software; the miniature events were defined as amplitude above a preset baselinenoise level $(5 \mathrm{pA})$ and reviewed visually by the investigator before analyses.

Drug application. Pharmacological sensitivity and drug testing were conducted by superfusion with known concentrations of substances until equilibrium concentrations were established (minimum $10 \mathrm{~min}$ ). After the drug superfusion was discontinued, the return of the electrophysiological parameters under study to control levels was taken as evidence of recovery. To control for possible cumulative effects of a series of drug applications, a random "Latin square design" was used to generate all of the concentration-response curves. In addition, an interval of $20 \mathrm{~min}$ was established to minimize any effects of a previous drug exposure. Whenever technically possible, a complete concentration-response curve was collected from a single neuron in a single slice. In those slices in which a neuron could not be maintained for the time required to collect five different concentrations points $(5 \times 10 \mathrm{~min}$ for control plus $5 \times 10$ min for drug treatment plus $5 \times 20$ min for washout period, total $=200$ $\mathrm{min}$ ), each and all points were pooled to provide the data presented. In most cases only a single concentration could be obtained from a single slice. CRF [rat/human CRF(r/h)], [Ucn I(rat)], $\alpha$-helical $\mathrm{CRF}_{(9-41)}$, picrotoxin, bicu- 
culline methiodide, CGP55845, and tetrodotoxin were obtained from Sigma (St. Louis, MO); D(-)-2-amino-5-phosphonopentanoic acid (D-APV), and DNQX were from RBI (Natick, MA); stressin $_{1}$, astressin, astressin ${ }_{2}-B$ (Ast ${ }_{2}-$ B), and mouse urocortin II (Ucn II) were from J. Rivier (Clayton Foundation Laboratories for Peptide Biology, The Salk Institute for Biological Studies, San Diego, CA); NBI 27914 was from D. Grigoriadis (Neurocrine, San Diego, CA); and antalarmin was from E. Webster (National Institutes of Health, Bethesda MD). Peptides and CRF antagonists were water-soluble and dissolved in the ACSF.

Analysis of data. Experiments were conducted using a paired protocol, i.e., each neuron served as its own control before and subsequent to drug exposure. In analyzing EPSCs, $n$ refers to the number of neurons from which a minimum of 10 EPSCs were sampled, averaged, and compared in control solutions. Drug effects were determined statistically using a paired $t$ test with a level of $p \leq 0.05$ required for significance.

Statistical significance at the level of $p \leq 0.05$ was determined with a Kolmogorov-Smirnov (K-S) test when analyzing mEPSC events. The $\mathrm{K}-\mathrm{S}$ statistic tested the hypothesis that two data sets were drawn from the same distribution. The test relied on the fact that the value of the sampled cumulative density function was asymptotically normally distributed. mEPSCs were collected over a $20 \mathrm{~min}$ period (control) before and after application of $\mathrm{CRF}(\mathrm{r} / \mathrm{h})$ or Ucn I. Each collection period provided a sample size (number of individual mEPSC events) of $>750$ events. The total number of events in a sample determined the maximal cumulative fraction (1.0), whereas events of comparable size or frequency were designated as fractions of their cumulative maximum. Averaged values were given as the mean \pm SEM.

\section{Results}

\section{CRF-related peptides lack direct membrane effects}

We initially compared the actions of $\mathrm{CRF}(\mathrm{r} / \mathrm{h})$ and $\mathrm{Ucn} \mathrm{I}$ (rat) within the CeA and LSMLN. Under our recording conditions, neither CRF(r/h) nor Ucn I (5-250 nM) affected resting membrane potential $[-59 \pm 0.5 \mathrm{mV}$ in CeA $(n=59) ;-58 \pm 0.5 \mathrm{mV}$ in LSMLN $(n=49)]$ or input resistance $[105 \pm 5.1 \mathrm{M} \Omega$ in CeA $(n=40) ; 198 \pm 18.5 \mathrm{M} \Omega$ in $\operatorname{LSMLN}(n=45)]$ significantly or consistently in neurons recorded from either CeA $(n=78 ; 42$ with CRF and 36 with Ucn I) or LSMLN ( $n=59 ; 28$ with CRF and 31 with Ucn I) nuclei. These data suggested that these ligands did not have direct membrane actions within these nuclei at the concentrations and recording conditions used in this in vitro study.

\section{Excitatory transmission within the CeA and LSMLN synapses is glutamatergic}

Most of the fast excitatory transmission within the mammalian CNS is mediated by glutamate acting at ionotropic receptors. We used a typical pharmacological mixture, DNQX and D-APV, after blocking inhibitory transmission with $\mathrm{GABA}_{\mathrm{A}}$ (bicuculline methiodide and picrotoxin), and $\mathrm{GABA}_{\mathrm{B}}$ (CGP55845) antagonists to demonstrate that excitatory transmission at the CeA $(n=66)$ and LSMLN $(n=49)$ synapses is glutamatergic and mediated by activation of AMPA-kainate and NMDA receptors (Fig. 2). In all subsequent experiments in which EPSC data were reported, brain slices were superfused with a mixture of picrotoxin, bicuculline methiodide, and CGP55845 added to the normal ACSF.

\section{CRF-related peptides depress and facilitate evoked excitatory transmission}

In the CeA, two different synapses were analyzed by activation of the VAP- and BLA-CeA pathways. In the CeA, CRF $(\mathrm{r} / \mathrm{h})(n=$ 36) (Fig. 3A) depressed whereas Ucn I $(n=30)$ (Fig. 3B) facilitated excitatory synaptic transmission at both synapses. As noted above (Fig. 2), monosynaptic EPSCs were isolated by the presence of a pharmacological mixture consisting of bicuculline methiodide, picrotoxin, and CGP55845. The EPSC depressant ac-

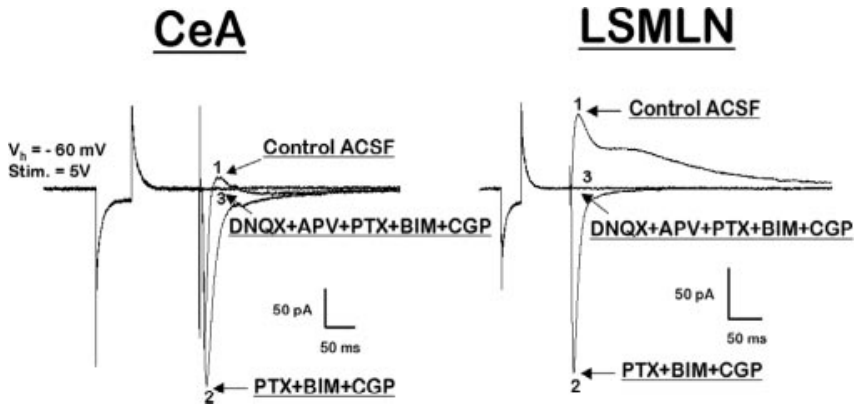

Figure 2. Pharmacological antagonists identified glutamate as the mediator of excitatory transmission within the CeA and LSMLN. Left, EPSC evoked by stimulation of the VAP-CeA pathway (comparable responses obtained at BLA-CeA pathway not depicted); right, LSMLN. (1) Evoked postsynaptic currents in control ACSF solution. (2) EPSC isolated initially from fast and slow inhibitory postsynaptic currents with picrotoxin (PTX), bicuculline methiodide (BIM), and CGP55845 (CGP). (3) The remaining glutamatergic EPSC is then blocked with the addition of DNQX and D-APV.

tion of $\mathrm{CRF}(\mathrm{r} / \mathrm{h})$ occurred with an identical efficacy (maximum depression to $30 \%$ of control) and potency $\left(\mathrm{IC}_{50} \cong 0.32 \mathrm{nM} ; n=\right.$ 18 ) at each synapse. On the other hand, Ucn I caused an initial modest concentration-dependent depression and then facilitated EPSCs at each synapse, but with a slight difference in efficacy and potency.

\section{CRF receptors mediating depression or facilitation of EPSCs in the CeA}

To identify receptors underlying the actions of these CRF-related peptide ligands, we tested several CRF receptor antagonists. Surprisingly, application of two synthetic nonpeptide antagonists, NBI 27914 (McCarthy et al., 1999), which is selective for $\mathrm{CRF}_{1}$, and antalarmin, which is selective for $\mathrm{CRF}_{1} \gg \mathrm{CRF}_{2}$ (Webster et al., 1996), resulted in facilitation of EPSC amplitudes (Fig. 4A) (ranging from $125 \pm 5$ to $155 \pm 5 \% ; n=5$ ) in the absence of exogenous $\mathrm{CRF}(\mathrm{r} / \mathrm{h})$ or $\mathrm{Ucn}$ I at both CeA synapses. This finding suggested a tonic, endogenous, possibly constitutive activation of $\mathrm{CRF}_{1}$ receptors to allow persistent $\mathrm{CRF}_{1}$-mediated dampening of excitatory transmission. Others have suggested that constitutively active synaptic signaling could be a form of activitydependent plasticity: "metaplasticity" (Abraham and Bear, 1996) or "priming" (Blank et al., 2002). We considered this tonic effect at CRF receptors to be a modulation in (1) metabolically dependent signaling processes, e.g., multiple second messenger cascades altered by kinases, phosphatases, etc., or a modulation in (2) the frequency or amplitude of glutamate-mediated miniature synaptic currents, or both. "Tonic" effects were distinguished from "phasic" effects. The latter would represent temporary or "on-demand" changes in endogenous ligand concentrations or after exogenous application of CRF-related peptide ligands and would induce a facilitation or depression of EPSCs.

Blocking $\mathrm{CRF}_{1}$ resulted in enhanced excitatory transmission caused perhaps by a tonic facilitation of excitatory glutamatergic transmission by $\mathrm{CRF}_{2}$ or depression by $\mathrm{CRF}_{1}$ in the amygdala, or both. This notion was supported by experiments showing that peptide antagonists with affinities for $\mathrm{CRF}_{2}>\mathrm{CRF}_{1}$ resulted in depression of EPSC amplitudes (Fig. $4 B$ ) (ranging from $45 \pm 6$ to $76 \pm 9 \%$ of control; $n=5)$ when applied alone. In general, $\alpha$-helical-CRF ${ }_{(9-41)}$ tends to exhibit an affinity for $\mathrm{CRF}_{2}>\mathrm{CRF}_{1}$, whereas astressin has an almost equivalent affinity for $\mathrm{CRF}_{2} \cong$ $\mathrm{CRF}_{1}$ (Dautzenberg et al., 2001). The depressant effects on excitatory glutamatergic transmission observed with the mixed an- 


\section{CeA}
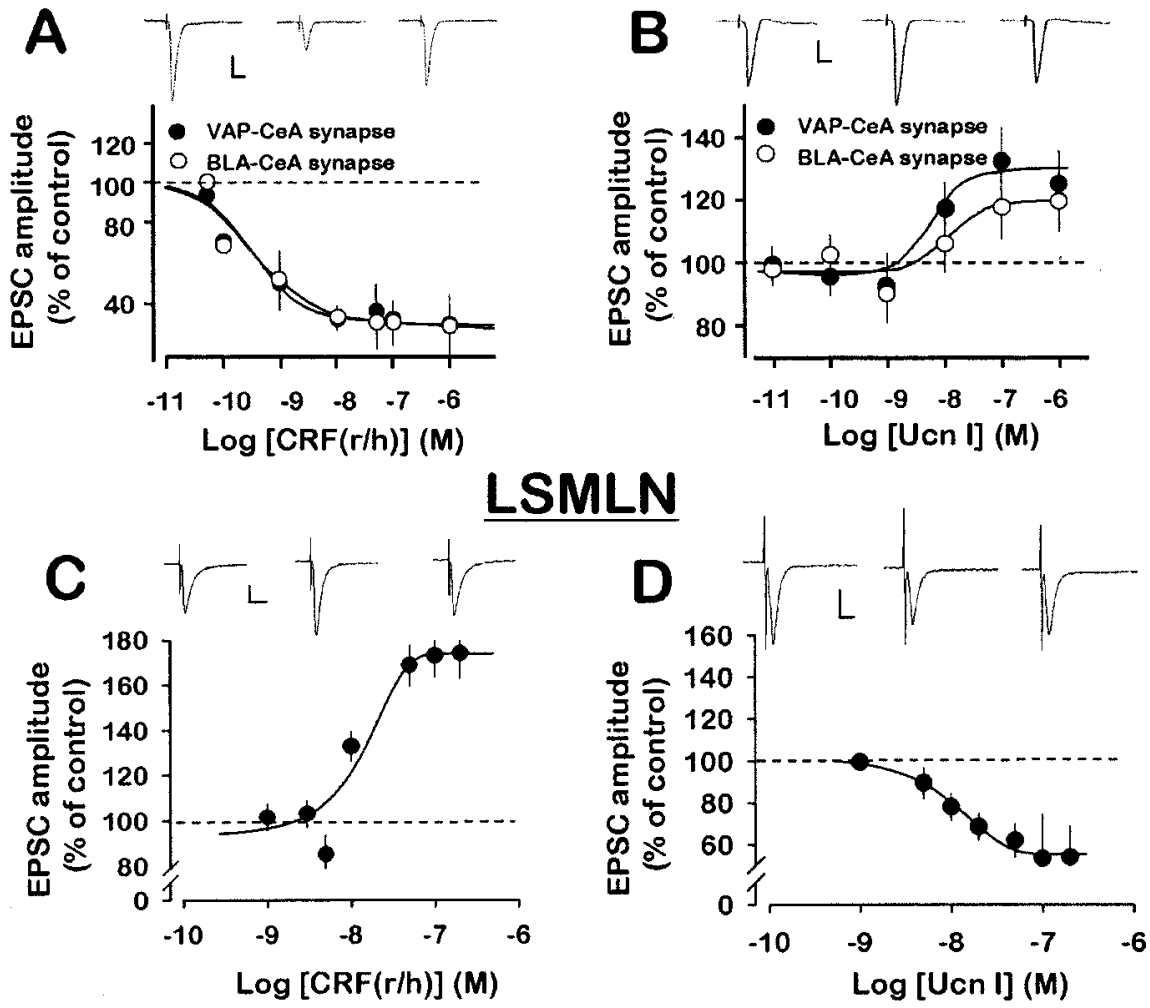

Figure 3. CRF(r/h) and Ucn I affect excitatory glutamatergic transmission in opposite directions in the CeA and LSMLN. $A, B$, Concentration-response curves for depression or facilitation of EPSCs by CRF or Ucn I at two CeA pathways. C, D, Concentrationresponse curves show opposite effects of CRF and Ucn I on EPSCs in LSMLN. Each point represents the mean \pm SEM. Traces in $A-D$ depict EPSCs in control ACSF with GABA receptor antagonists (left), in the presence of CRF(r/h) or Ucn I (middle), respectively, and after a 30 min wash (right). Calibration: 50 pA, 20 msec.
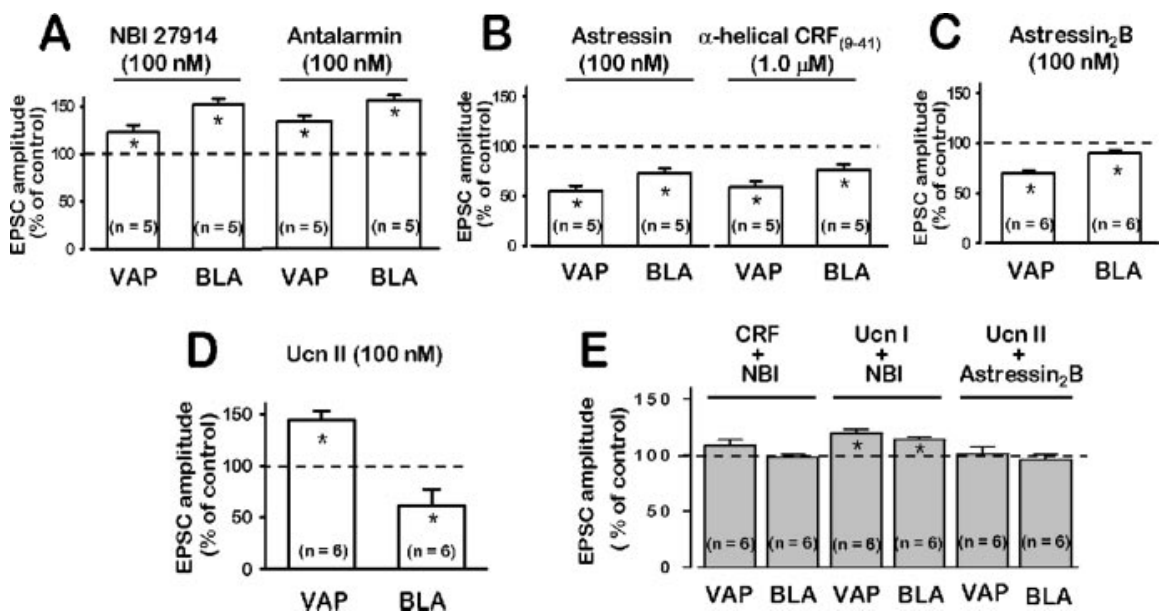

Figure 4. Different effects of CRF receptor nonpeptide (NBI 27914, antalarmin) and peptide (astressin, $\alpha$-helical-CRF $(9-41)$ and astressin $2-B$ ) antagonists observed at two CeA excitatory glutamatergic synapses. A, At VAP- and BLA-CeA synapses, NBI 27914 (100 nm) and antalarmin (100 nm) resulted in facilitation of EPSC. B, Astressin(100 nm) and $\alpha$-helical CRF ${ }_{(9-41)}(1 \mu \mathrm{m})$ depressed EPSC amplitude. C, Astressin $2-B(100 \mathrm{~nm})$, a selective CRF $_{2}$ antagonist, depressed EPSCs more effectively in the VAPcompared with the BLA-CeA synapse. Note also a greater degree of depression in the VAP-CeA compared with the BLA-CeA (A-C). D, Ucn II (100 nm), a selective CRF, agonist, facilitated VAP-CeA, whereas it depressed BLA-CeA EPSCs. E, After 10 min pretreatment with NBI $27914(100 \mathrm{~nm})$ and in its continued presence, NBI 27914 blocked the depressant action of CRF(r/h) $(50 \mathrm{~nm})$ at both synapses but did not affect facilitation by $U \mathrm{cn}$ I at either synapse. Similar treatment with astressin ${ }_{2}-B(100 \mathrm{~nm})$ blocked the facilitation by Ucn II (100 nm) at the VAP-CeA and also blocked Ucn II (100 nm) depression of EPSCs at the BLA-CeA synapse. tagonist $\alpha$-helical $\mathrm{CRF}_{(9-41)}$ would be expected for a $\mathrm{CRF}_{2}$-preferring antagonist blocking a tonically activated $\mathrm{CRF}_{2}$ receptor. Ast $-\mathrm{B}$, a selective $\mathrm{CRF}_{2}$ antagonist (Rivier et al., 2002; J. Rivier, personal communication), itself depressed basal EPSC amplitude significantly in the CeA when administered alone (Fig. 4C). This result was similar to those observed with other CRF-related peptide receptor antagonists, e.g., NBI 27914, antalarmin, $\alpha$-helical$\mathrm{CRF}_{(9-41)}$, and astressin. $\mathrm{Ast}_{2}-\mathrm{B}$ was more effective at unmasking a $\mathrm{CRF}_{1}$-mediated depression in the VAP-CeA versus the BLA-CeA synapse. The depressant effect of $\mathrm{CRF}(\mathrm{r} / \mathrm{h})$ on excitatory transmission in both CeA pathways was blocked completely by NBI 27914 (Fig. 4E), whereas facilitation induced by Ucn I was not affected (Fig. 4E). These data suggested that $\mathrm{CRF}_{1}$ and $\mathrm{CRF}_{2}$ generate and mediate a negative and positive tone, respectively, on excitatory glutamatergic transmission in the CeA.

Newer, more selective endogenous agonists, urocortin II and urocortin III, for $\mathrm{CRF}_{2}$ receptors were identified in rodents and humans (Lewis et al., 2001; Reyes et al., 2001). Similar to Ucn I (Fig. 3B), Ucn II $(100 \mathrm{nM})$ (Fig. $4 D)$ facilitated EPSCs in the VAP-CeA pathway, but in contrast to Ucn I, Ucn II depressed EPSC amplitude at the BLA-CeA synapse (Fig. 4D). The selective $\mathrm{CRF}_{2}$ antagonist, Ast ${ }_{2}-\mathrm{B}$, blocked completely the Ucn II-induced facilitation of EPSCs at the VAP-CeA pathway and also the depression by Ucn II measured at the BLA-CeA synapse (Fig. 4, compare $E, D$ ).

Receptors for CRF-related peptides and their facilitation or depression of EPSCs in the LSMLN

In contrast to the CeA (Figs. $3 A, B$, and 4 vs $3 C, D$ and 5$), C R F(r / h)$ facilitated whereas Ucn I depressed EPSC amplitude at LSMLN synapses. Within the LSMLN, CRF $(\mathrm{r} / \mathrm{h})$ caused a concentration-dependent facilitation of excitatory transmission, especially at higher concentrations $\left(10-200 \mathrm{nM} ; \mathrm{EC}_{50} \cong\right.$ $15 \mathrm{~nm} ; n=23$ ) (Fig. 3C). In contrast, Ucn I $\left(\mathrm{IC}_{50} \cong 13 \mathrm{~nm} ; n=26\right)$ depressed EPSC amplitude over the similar concentration range (Fig. 3D). These results in the LSMLN are opposite those in the CeA.

On the other hand (as in the CeA), antagonists of CRF-related peptides within the LSMLN unmasked tonic activation of $\mathrm{CRF}$ receptors. The selective $\mathrm{CRF}_{1}$ antagonist, NBI 27914, resulted in depression of EPSCs and blocked CRF-induced facilitation of EPSC amplitude (Fig. 5A, middle, $D)$. In contrast, the Ucn I-induced depres- 
sion of EPSC amplitude (Fig. 5A, bottom, $D)$ was not altered by NBI 27914, suggesting that NBI 27914 released a tonic $\mathrm{CRF}_{2}$ mediated depression of EPSCs within the LSMLN.

A new and highly selective $\mathrm{CRF}_{1}$ peptide agonist, stressin ${ }_{1}(100 \mathrm{nM})$ (Rivier et al., 2001; J. Rivier, personal communication), facilitated LSMLN EPSCs (Fig. 5B) to the same extent $(167 \pm 15 \%)$ (Fig. $5 E$ ) as a comparable concentration of $100 \mathrm{nM}$ $\mathrm{CRF}(\mathrm{r} / \mathrm{h})$ (Fig. 3C). The selective peptide $\mathrm{CRF}_{2}$ antagonist (Rivier et al., 2002), Ast $_{2}$-B (100 nM) (Fig. 5C, top and bottom, $E)$, enhanced EPSC amplitude, whereas it did not block the facilitatory action of $\mathrm{CRF}(\mathrm{r} / \mathrm{h})$ on excitatory glutamatergic transmission (Fig. 5C, top, E). In contrast, the depressant effect of Ucn I on excitatory glutamatergic transmission was blocked completely by Ast $_{2}$-B (Fig. $5 C$, bottom, $E$ ), and a facilitatory action of Ucn I on EPSCs in LSMLN neurons was unmasked (Fig. $5 C$, bottom, E). Furthermore, astressin, which has an almost equivalent affinity at $\mathrm{CRF}_{2} \cong \mathrm{CRF}_{1}$ (Dautzenberg et al., 2001), had little effect on the EPSC amplitude $(94.5 \pm 4.5 \% ; n=6 ; p>0.05)$ in the LSMLN compared with control. These data support the hypothesis that the facilitating action of $\mathrm{CRF}(\mathrm{r} / \mathrm{h})$ at excitatory glutamatergic synapses within the LSMLN may be mediated by a $\mathrm{CRF}_{1}$ receptor, whereas the Ucn I depressant action may be mediated through a $\mathrm{CRF}_{2}$ receptor.

The availability and use of different antagonists provided results that emphasize the complex distribution of these receptors within the LSMLN and CeA. Because Ucn II has no affinity for the CRF-binding protein (Reyes et al., 2001), it is unlikely that $\mathrm{CRF}_{2}$ requires the CRF-binding protein for activation in either CeA or LSMLN neurons.

\section{CRFs affect mEPSCs}

To examine the presynaptic versus postsynaptic site of action of the endogenous ligands $\mathrm{CRF}(\mathrm{r} / \mathrm{h})$ and $\mathrm{Ucn} \mathrm{I}$, we recorded their effects on the frequency of spontaneous mEPSCs, an indicator of presynaptic action, and amplitude, a gauge of postsynaptic action. mEPSCs were measured in the presence of picrotoxin (50 $\mu \mathrm{M})$, bicuculline $(10 \mu \mathrm{M})$, CGP55845 $(2 \mu \mathrm{M})$, and tetrodotoxin (1 $\mu \mathrm{M})$ in standard extracellular solution to block $\mathrm{GABA}_{\mathrm{A}}-\mathrm{GABA}_{\mathrm{B}}$ receptor activity and voltage-dependent sodium channels, respectively.

\section{mEPSCs in the CeA}

Because the CeA contains CRF neurons, CRF autoreceptors may be present and innervated by CRF terminals from intrinsic CRF cell bodies (Harrigan et al., 1994). Figure 6, $B$ and $D$, represents normalized cumulative amplitude and interevent interval distribution curves for a control and either a CRF- or an Ucn I-treated neuron recorded from the CeA. In the presence of CRF $(\mathrm{r} / \mathrm{h})(50$ $\mathrm{nM}$ ), both curves were shifted to the left, i.e., CRF depressed the amplitude while increasing the frequency (decreasing the interevent interval) of mEPSCs compared with control. CRF(r/h) de-
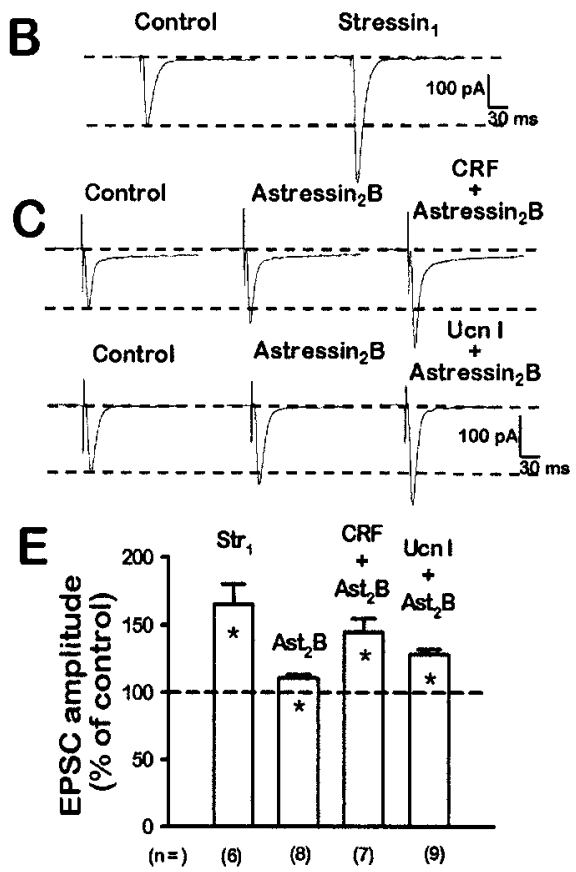

Figure 5. $\mathrm{CRF}_{1}$ and $\mathrm{CRF}_{2}$ receptor activation tonically regulate EPSC amplitude in the $\mathrm{LSMLN}$. $A$, Top, $\mathrm{CRF}(\mathrm{r} / \mathrm{h}, 50 \mathrm{~nm})$ facilitated hereas Ucn I (100 nm) depressed LSMLN EPSCs. Middle, NBI 27914 (100 nm) resulted in depression of baseline EPSCS and

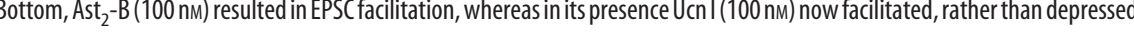
$\mathrm{nm}$; (RF 1 agonist) and Ast $-\mathrm{B}$ (100 nm; (RF 2 antagonist). Ast $-\mathrm{B}(100 \mathrm{~nm})$ did not block facilitation by $(R F(\mathrm{r} / \mathrm{h})(50 \mathrm{~nm})$, whereas $\mathrm{Ast}_{2}-\mathrm{B}$ reversed Ucn I $(50 \mathrm{~nm})$ depression to facilitation

creased significantly the mean mEPSC amplitude from $17.4 \pm 0.4$ to $14.5 \pm 0.2 \mathrm{pA}(p<0.01 ; n=6)$, whereas the frequency was increased significantly from 3.9 to 4.7 mEPSCs per second (a decreased interevent interval from $256 \pm 11 \mathrm{msec}$ in control to $215 \pm 8 \mathrm{msec}$ with CRF). Ucn I (200 nM), on the other hand, significantly increased the amplitude of mEPSCs from $18.6 \pm 0.3$ to $21.6 \pm 0.2 \mathrm{pA}(p<0.01 ; n=6)$, shown as a shift to the right in Figure $6 D$. Similar to CRF, but exerting a more robust effect, $U c n$ I shifted the normalized cumulative interevent interval distribution curve to the left (Fig. $6 D$ ), with an average increased mEPSC frequency from 4.5 to 12.3 mEPSCs per second (a decreased interevent interval from $220 \pm 11 \mathrm{msec}$ in control to $81 \pm 2 \mathrm{msec}$ with Ucn I). These effects of CRF and Ucn on mEPSCs were summarized in Figure 8 (bottom left). We have assigned the CRF increase in mEPSC frequency to a $\mathrm{CRF}_{2}$ - rather than a $\mathrm{CRF}_{1}$ mediated action on the basis of our data with evoked EPSCs and CRF receptor selective antagonists (Fig. 4). CRF(r/h) effects on mEPSC amplitude and frequency in the CeA suggested that its postsynaptic depressant action prevailed over a presynaptic facilitatory action when the effects of CRF on evoked EPSCs were compared (Figs. $3 A, 8$, bottom left). Because both $\mathrm{CRF}_{1}$ and $\mathrm{CRF}_{2}$ receptor activation may occur postsynaptically, preferential activation of one or the other postsynaptic receptor in conjunction with activation of the presynaptic $\mathrm{CRF}_{2}$ receptor would result in depression $\left(\mathrm{CRF}_{1}\right)$ or facilitation $\left(\mathrm{CRF}_{2}\right)$, respectively (Fig. 8).

mEPSCs in the LSMLN

In the LSMLN, CRF $(\mathrm{r} / \mathrm{h})(50 \mathrm{nM})$ produced a statistically significant increase in the amplitude (Fig. 7A) (mean amplitude in- 


\section{AMYGDALA}

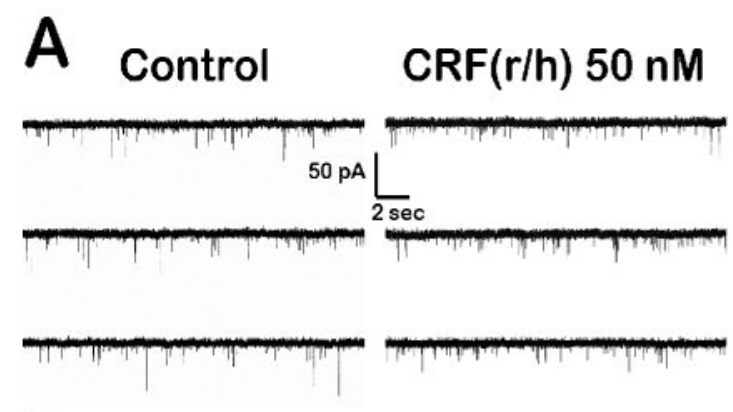

B

$\mathrm{r} / \mathrm{h}$ CRF $50 \mathrm{nM}$
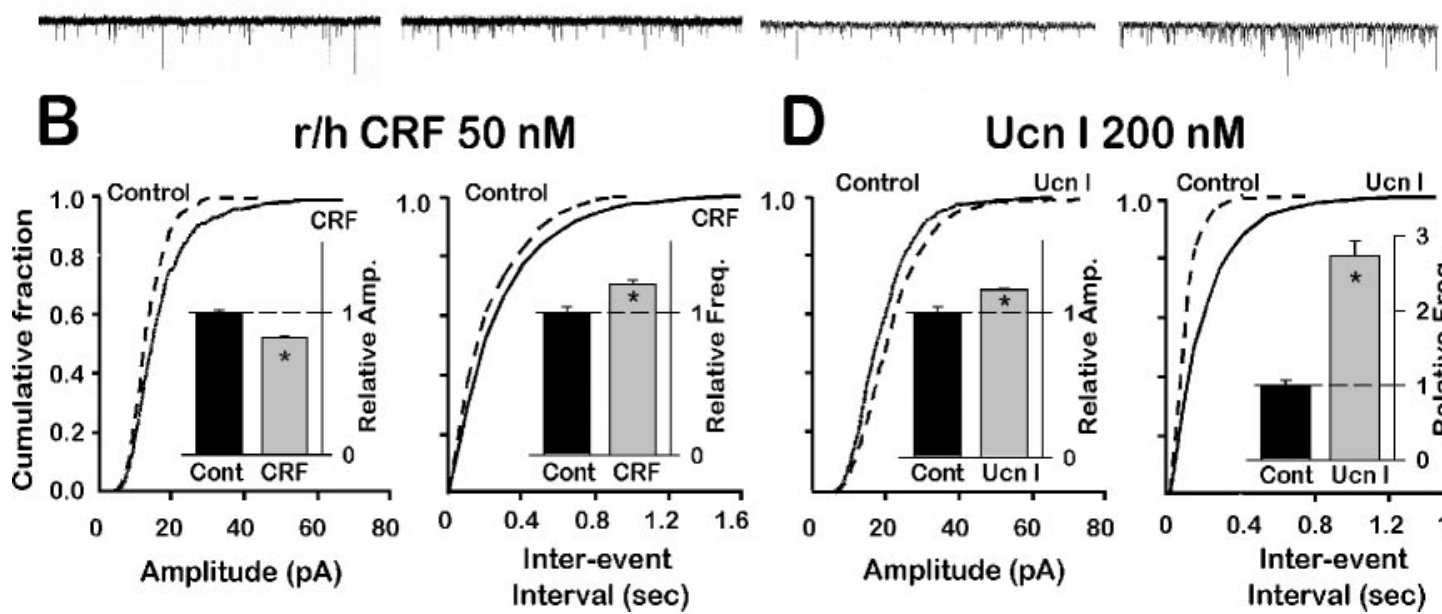

Ucn I $200 \mathrm{nM}$

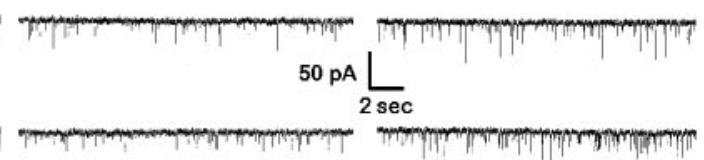

Amplitude (pA)

Figure 6. CRF(r/h) and Ucn I affected mEPSCS differently in the CeA. $A$, Typical traces of $\mathrm{mEPSCS}$ before and after $\mathrm{CRF}(\mathrm{r} / \mathrm{h})(50 \mathrm{~nm}) . B$, Graph of cumulative fraction of $\mathrm{mEPSCs}$ from single cell depicted in $A$ and plotted as a function of amplitude ( $p<0.005$; maximum amplitude difference was 0.11 by $\mathrm{K}-\mathrm{S}$ test). Interevent interval ( $p<0.005$; maximum difference was 0.11 by $\mathrm{K}-\mathrm{S}$ test). C, Typical traces of mEPSCs before and after Ucn I (200 nM).D, Graph of cumulative fraction of mEPSCs from single cell depicted in Cas a function of amplitude $(p<0.0001$; maximum amplitude difference was 0.11 by K-S test). Interevent interval ( $p<0.0001$; maximum interevent interval difference was 0.36 by K-S test). Insets depict average changes increase from control at $1.0(n=6)$.

creased from $17.0 \pm 0.5$ to $30.1 \pm 0.9 \mathrm{pA} ; p<0.01 ; n=5)$ without affecting the frequency of mEPSCs (the mean interevent interval was $297 \pm 14.7 \mathrm{msec}$ in control and $310 \pm 15.2 \mathrm{msec}$ in CRF-treated neurons; $p>0.05 ; n=5)$. On the other hand, Ucn I (200 nM) caused a significant depression of both amplitude and frequency of mEPSCs (Fig. 7C). The mean amplitude was larger in control (19.9 $\pm 0.5 \mathrm{pA})$ compared with Ucn I (14.6 $\pm 0.6 \mathrm{pA}$; $n=6 ; p<0.01)$. Furthermore, the mean interevent interval with $\mathrm{Ucn}$ I was longer (from $352 \pm 25.3$ to $991 \pm 62.3 \mathrm{msec} ; n=6 ; p<$ 0.01 ; mean frequency decreased from 2.8 to 1.0 mEPSCs per second). Figure $7, B$ and $D$, represents normalized cumulative amplitude and interevent distribution curves for a control and either CRF- or Ucn I-treated LSMLN neurons. These mEPSCs results were summarized and interpreted in Figure 8, bottom right.

To confirm a solely postsynaptic action for CRF in the LSMLN, we conducted paired-pulse facilitation (PPF) experiments, used as an indicator of a presynaptic locus of action, and monitored the ratio of the amplitudes of the second to the first of a pair of evoked EPSCs. CRF did not affect PPF in the LSMLN. These PPF data suggested only a postsynaptic action for CRF in the LSMLN and supported our findings of a lack of effect of CRF on mEPSC frequency (Figure $7 A, B$ ): after Ucn I at $35 \mathrm{msec}, 1.6 \pm$ 0.16 versus $1.9 \pm 0.10$; at $50 \mathrm{msec}, 1.3 \pm 0.12$ versus $1.5 \pm 0.08$; and at $150 \mathrm{msec}, 1.3 \pm 0.12$ versus $1.5 \pm 0.08$, respectively $(p<$ 0.05 at each of these stimulus intervals). Ucn I enhanced PPF (Fig. $7 F$ ), indicating a presynaptic inhibitory action because treatments decreasing transmitter release increase PPF (Katz and Miledi, 1968; Manabe et al., 1993); these data supported our find- ings (Fig. 7C,D) of a reduced mEPSC frequency in the LSMLN Our $\mathrm{mEPSC}$ and PPF data indicated the presence of $\mathrm{CRF}_{2}$ receptors on the glutamatergic terminals, similar to our previous data for the CeA. In the LSMLN, however, the presynaptic $\mathrm{CRF}_{2}$ was inhibitory, whereas in the CeA, the presynaptic $\mathrm{CRF}_{2}$ was facilitatory. These presynaptic $\mathrm{CRF}_{2}$ inhibitory receptors could be localized on CeA afferents to the LSMLN.

\section{Discussion}

The primary findings of this study are as follows: (1) in the CeA, $\mathrm{CRF}(\mathrm{r} / \mathrm{h})$ depressed excitatory glutamatergic transmission through a $\mathrm{CRF}_{1}$-mediated postsynaptic action, whereas Ucn I facilitated EPSCs via postsynaptic and presynaptic facilitatory $\mathrm{CRF}_{2}$-mediated mechanisms; (2) conversely, in the LSMLN, CRF caused a $\mathrm{CRF}_{1}$-mediated facilitation of excitatory glutamatergic transmission via postsynaptic mechanisms, whereas Ucn I depressed EPSCs via postsynaptic and presynaptic $\mathrm{CRF}_{2}$-mediated mechanisms; and (3) endogenous ligands for these receptors tonically and phasically affect excitatory glutamatergic transmission in the CeA and LSMLN. These data provided evidence that CRFrelated peptides function endogenously in neuronal circuits outside the HPA where they activate local synaptic receptors to modulate excitatory glutamatergic transmission.

Two endogenous ligands, $\mathrm{CRF}(\mathrm{r} / \mathrm{h})$ and $\mathrm{Ucn} \mathrm{I}$, each bind to both $\mathrm{CRF}_{1}$ and $\mathrm{CRF}_{2}$ receptors. In general, when $\mathrm{Ucn} \mathrm{I}$ is compared with $\mathrm{CRF}(\mathrm{r} / \mathrm{h})$ at either $\mathrm{CRF}_{1}$ or $\mathrm{CRF}_{2}$ receptors, $\mathrm{Ucn} \mathrm{I}$ is more potent (Hauger et al., 2003). Furthermore, Ucn I is also more potent (Vaughan et al., 1995) in releasing ACTH from anterior pituitary corticotropes, a $\mathrm{CRF}_{1}$-mediated response. On the 


\section{SEPTUM}
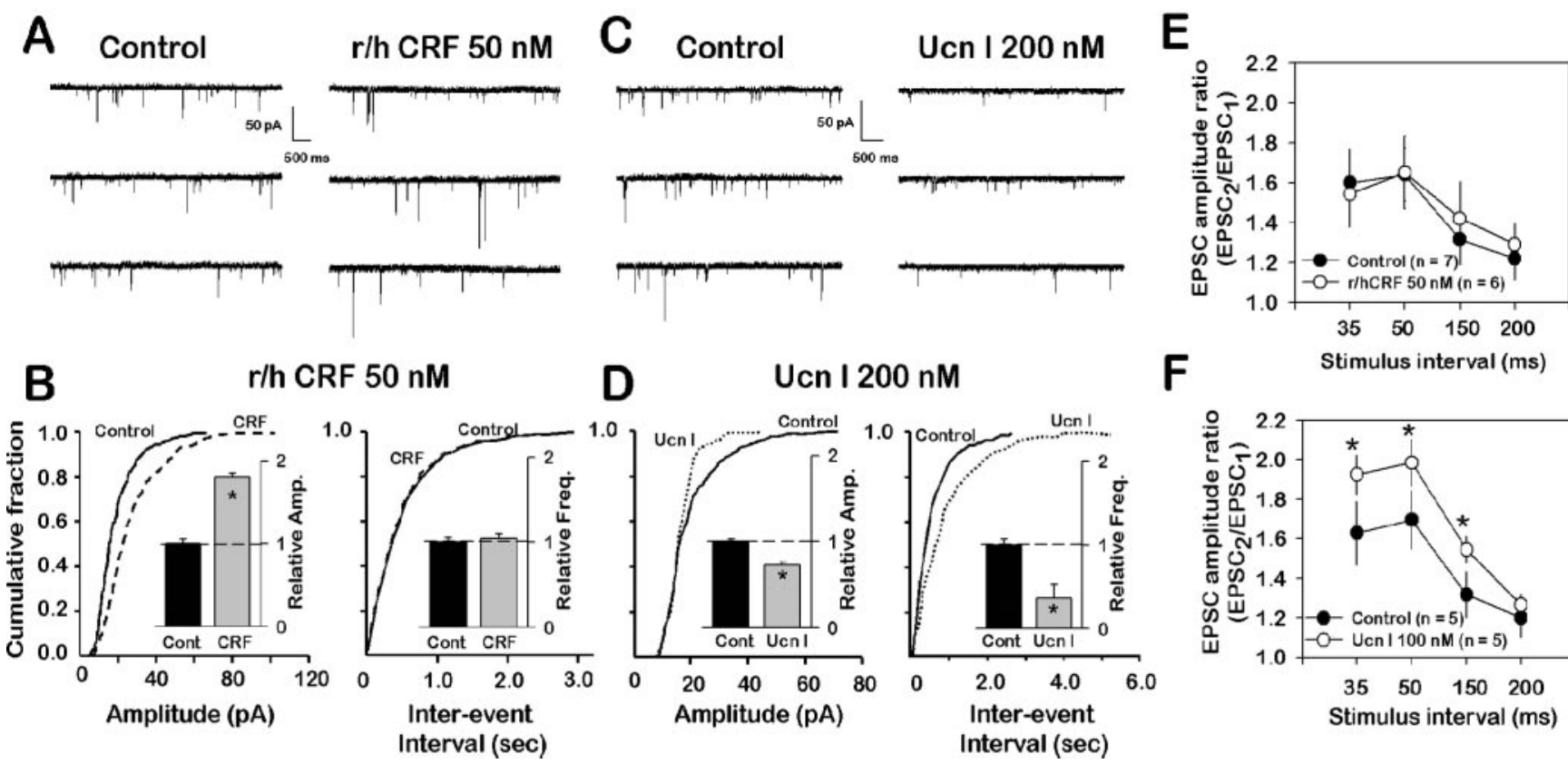

$\mathbf{F}$

Stimulus interval (ms)

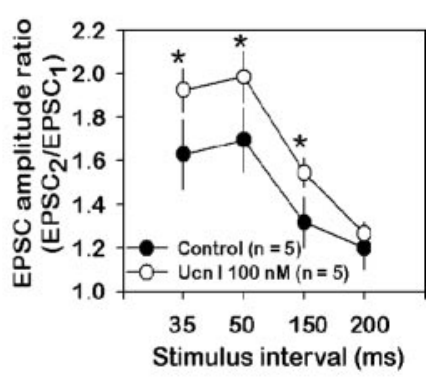

Figure 7. CRF(r/h) and Ucn I have different effects on $\mathrm{mEPSCS}$ within the LSMLN. A, Typical traces of $\mathrm{mEPSC}$ before and after $\mathrm{CRF}(\mathrm{r} / \mathrm{h})(50 \mathrm{~nm}) . B$, Graph of cumulative fraction of $\mathrm{mEPSC}$ from single cell depicted in $A$ and plotted as a function of amplitude ( $p<0.001$; maximum amplitude difference was 0.29 by K-S test). Interevent interval ( $p<0.401$ by K-S test). C, Ucn I ( $200 \mathrm{nm)}$ depressed the amplitude ( $p<0.0001$; maximum amplitude difference was 0.36 by $\mathrm{K}-\mathrm{S}$ test). Maximum difference of the interevent interval was 0.42 by $\mathrm{K}-\mathrm{S}$ test). Insets depict decrease from control at $1.0(n=5)$ of mEPSCS. D, Graphic plot of the effect of Ucn I on the cumulative fraction of mEPSCs as a function of mEPSC amplitude and interevent interval. $E_{\text {, Plot of EPSC }} / E P S C_{1}$ ratio versus interstimulus intervals of EPSCS before (control) and in the presence of CRF(r/h); CRF did not affect this ratio. $F, U$ (nn I increased the $\operatorname{EPSC}_{2} / \mathrm{EPSC}_{1}$ ratio significantly $\left({ }^{*} p<0.05 ; n=5\right)$, especially at the shorter intervals.

other hand, in a different functional assay, $\mathrm{CRF}(\mathrm{r} / \mathrm{h})$ is more potent at $\mathrm{CRF}_{1}$ and $\mathrm{Ucn} \mathrm{I}$ is more potent at $\mathrm{CRF}_{2}$ in stimulating cAMP (Hauger et al., 2003). Thus, in addition to the specific ligand, the coupling of the respective receptors to their effectors and the site at which the endogenous receptors are expressed can all affect and define the potency of the ligand when function is used to measure outcome. We used $\mathrm{CRF}(\mathrm{r} / \mathrm{h})$ and $\mathrm{Ucn} \mathrm{I}$, the endogenous ligands for $\mathrm{CRF}_{1}$ and $\mathrm{CRF}_{2}$, along with selective agonists and antagonists for $\mathrm{CRF}_{1}$ and $\mathrm{CRF}_{2}$ to define CRF receptors and their synaptic actions within two limbic nuclei.

We investigated two different CeA pathways: the VAP-CeA provides afferent inputs from brainstem areas, whereas the BLACeA pathway carries intra-amygdala information (Alheid and Heimer, 1988). Both CeA synapses exhibited an equivalent level of depression and an identical $\mathrm{IC}_{50}$. A CRF $\mathrm{CR}_{1}$-mediated depressant action of EPSCs within the CeA was based on its antagonism by the selective $\mathrm{CRF}_{1}$ antagonists NBI 27914 or antalarmin (Fig. 4). On the other hand, Ucn I (Fig. 3), at concentrations 20- to 50-fold greater than $\mathrm{CRF}(\mathrm{r} / \mathrm{h})$, facilitated glutamatergic EPSCs. Interestingly, $U \mathrm{cn} I$, unlike $\mathrm{CRF}(\mathrm{r} / \mathrm{h})$, was more effective and potent in the VAP- versus BLA-CeA pathway (Fig. 3B). Postsynaptic and presynaptic $\mathrm{CRF}_{2}$ contributed to Ucn I facilitation because the selective $\mathrm{CRF}_{2}$ antagonist, Ast ${ }_{2}-\mathrm{B}$, blocked the facilitation of $\mathrm{EP}$ SCs induced by the selective $\mathrm{CRF}_{2}$ agonist, $\mathrm{Ucn}$ II (Fig. $4 D, E$ ). Furthermore, Ucn I and CRF each increased the frequency of mEPSCs in the CeA (Figure 6). The differences in effective concentrations between ligands at the specific CeA synapses may be related to the relative abundance of a receptor type, the differential linking of second messenger systems, and different locations of receptors within a synapse (presynaptic versus postsynaptic). Figure 8 depicts a summary of our results.

We propose that during "normal" physiological conditions, termed "homeostasis" (Dallman, 2003; McEwen and Wingfield, 2003), when lower endogenous $\mathrm{CRF}(\mathrm{r} / \mathrm{h})$ concentrations may occur within the CeA, $\mathrm{CRF}_{1}$ activation results preferably in depression of EPSCs. On the other hand, with higher concentrations of CRF-related peptides, both $\mathrm{CRF}_{1}$ and $\mathrm{CRF}_{2}$ will be activated. If the endogenous ligand or a drug preferred $\mathrm{CRF}_{1}$ receptors, then depression of the excitatory drive from the VAP or BLA to the CeA would be expected because lower $\mathrm{CRF}_{1}$ agonist concentrations result in maximal depression of EPSCs. If a ligand preferred $\mathrm{CRF}_{2}$ receptors (Ucn II), however, then a mechanism to facilitate excitatory drive onto the CeA, especially its input from the VAP-CeA pathway, would be enhanced while simultaneously depressing EPSCs in the LSMLN (Fig. 3).

Within the LSMLN, the effective concentration range for both $\mathrm{CRF}(\mathrm{r} / \mathrm{h})$ and $\mathrm{Ucn}$ I was greater than $\mathrm{CRF}(\mathrm{r} / \mathrm{h})$ but was similar to that of Ucn I in the CeA. This might be expected because the LSMLN exhibits the highest density for $\mathrm{CRF}_{2}$ receptors in the brain (Chalmers et al., 1995; Li et al., 2002). Furthermore, unlike the CeA, CRF $(\mathrm{r} / \mathrm{h})$ had no effect on mEPSC frequency or PPF, whereas Ucn I exhibited a lower effective concentration, reduced mEPSC frequency, and enhanced PPF; these latter data provide evidence for a presynaptic inhibitory $\mathrm{CRF}_{2}$. Activation of both postsynaptic $\mathrm{CRF}_{1}$ (facilitation) and presynaptic and postsynaptic $\mathrm{CRF}_{2}$ (depression) could cancel the effects of each. The higher effective concentrations required by either ligand in the LSMLN compared with the CeA could suggest that unless endogenous 


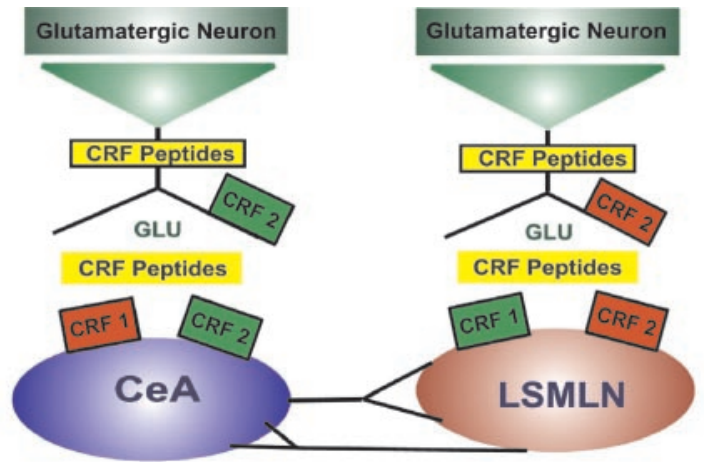

\begin{tabular}{|c|c|c|c|c|c|c|c|}
\hline \multicolumn{4}{|c|}{$\mathrm{CeA}$} & \multicolumn{4}{|c|}{ LSMLN } \\
\hline & $\begin{array}{l}\text { CRF } \\
\text { [R1] }\end{array}$ & $\begin{array}{l}\text { Ucn } 11 \\
{[R 2]}\end{array}$ & Interpretation & & \begin{tabular}{|l} 
CRF \\
[R1]
\end{tabular} & $\begin{array}{l}\text { Ucn 1 } \\
\text { [R2] }\end{array}$ & Interpretation \\
\hline $\begin{array}{c}\text { mEPSC } \\
\text { Frequency }\end{array}$ & $*$ & - & $\begin{array}{c}\text { Pre-synaptic } \\
+ \text { +R2 }\end{array}$ & $\begin{array}{c}\text { mEPSC } \\
\text { Frequency }\end{array}$ & 0 & 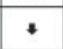 & $\begin{array}{c}\text { Pre-synaptic } \\
-R 2\end{array}$ \\
\hline $\begin{array}{c}\text { mEPSC } \\
\text { Amplitude }\end{array}$ & + & $\uparrow$ & $\begin{array}{c}\text { Post-synaptic } \\
-\mathrm{R} 1 ;+\mathrm{R} 2\end{array}$ & $\begin{array}{c}\text { MEPSC } \\
\text { Amplitude }\end{array}$ & 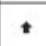 & 4 & $\begin{array}{c}\text { Post-synaptic } \\
+ \text { +R1; -R2 }\end{array}$ \\
\hline $\begin{array}{l}\text { Evoked } \\
\text { EPSC } \\
\text { Amplitude }\end{array}$ & + & $t$ & $\begin{array}{c}\text { Pre-synaptic, +R2 } \\
\text { Post-synaptic } \\
-\mathrm{R} 1 ;+\mathrm{R} 2\end{array}$ & $\begin{array}{l}\text { Evoked } \\
\text { EPSC } \\
\text { Amplitude }\end{array}$ & $\uparrow$ & 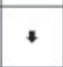 & $\begin{array}{c}\text { Pre-synaptic, -R2 } \\
\text { Post-synaptic } \\
\text { +R1;-R2 }\end{array}$ \\
\hline
\end{tabular}

* CRF activation of $\mathrm{CRF}_{2}$, not $\mathrm{CRF}_{1}$

Figure 8. Diagrams depicting presynaptic and postsynaptic distribution and function of $C_{\text {. }}$. DF and $\mathrm{CRF}_{2}$ within two limbic pathways. Tonic and phasic activation of $\mathrm{CRF}_{1}$ or $\mathrm{CRF}_{2}$ receptors regulates excitatory glutamatergic transmission positively by facilitation (green) or negatively by depression (red). Endogenous CRF peptides may be co-released from nerve terminals (intracellularly; (RF Peptides enclosed inside yellow retangle on nerve terminals) or be circulated and maintained in the extracellular space (CRF Peptides as unbound yellow rectangle and free in synaptic spaces), or both. Left (at (eA), CRF located postsynaptically; activation leads to depression of EPSC amplitude. CRF located presynaptically and postsynaptically; activation may lead to enhanced glutamate release and facilitation of EPSC amplitude, but end result also depends on level of CRF $_{1}$ activation. Right (at LSMLN), CRF $_{1}$ located postsynaptically; activation leads to facilitation of EPSC amplitude. CRF located postsynaptically and presynaptically; activation leads to depression of EPSC amplitude, but result depends on net $\mathrm{CRF}_{1}$ and $\mathrm{CRF}_{2}$ effects. Tables below diagram (Left, CeA; right, LSMLN) summarize mEPSC and evoked EPSC data and suggest CRF receptor types mediating the respective results.

ligand levels are elevated, e.g., during stress, the role for CRFrelated peptides during normal physiological conditions within these two nuclei would be to depress excitatory transmission in the CeA.

Our data indicate that $\mathrm{CRF}_{1}$ and $\mathrm{CRF}_{2}$ receptors are colocalized postsynaptically in the LSMLN and that their selective or possibly mixed activation mediates conspicuously opposite actions (Figs. 3, 8). Dautzenberg and Hauger (2002) also depicted such a cellular colocalization. Cellular colocalization of different receptors for the same or similar ligand (e.g., another member of the CRF-related peptides) suggests that different second messenger systems and downstream proteins could be responsible for mediation of CRF-related peptide transduction mechanisms. Because our data indicate that excitatory glutamatergic synaptic transmission can be affected by the prevailing tone of the endogenous ligands at $\mathrm{CRF}_{1}$ and $\mathrm{CRF}_{2}$ receptors, an imbalance of CRFrelated peptide receptor tone within the LSMLN opens this modulation to possible regulation by various factors and environmental conditions. Because LSMLN neurons are linked directly to the CeA (Jakab and Leranth, 1995), an imbalance within the LSMLN would also cause an imbalance in the CeA. Furthermore, CRF axons from the CeA project to the LSMLN (Jakab and Leranth, 1995) and would also modulate transmission within the LSMLN.

What might be the functional relevance of the concentrationdependent effects of CRF-related peptides in normal excitatory glutamatergic synaptic transmission and what is the source of endogenously released CRF-related peptides acting within the LSMLN or CeA? Importantly, anxiety-like behavioral and autonomic effects after centrally administered CRF are not dependent on CRF-induced HPA-released ACTH or corticosteroids, because these anxiety-related outcomes persist in hypophysectomized rats (Eaves et al., 1985) and in mice conditionally knocked out for $\mathrm{CRF}_{1}$ (Müller et al., 2003). Bremner et al. (1997) reported higher levels of CRF (137\%) in CSF of patients diagnosed with chronic combat-related posttraumatic stress disorder versus CSF-CRF in comparison subjects (100\%). Subsequently, Vythilingam et al. (2000) concluded that in healthy humans, CSF-CRF represented CRF derived primarily from non-HPA CRF neurons rather than HPA-axis CRF neurons projecting from the paraventricular nucleus of the hypothalamus. These non-HPA-mediated modulatory actions may be caused by circulating CRF-related peptides (Rothman et al., 2002), or may be the result of CRFrelated peptides released locally from neurons where it may be colocalized with a variety of transmitters, including glutamate (Sauvage and Steckler, 2001; King and Bishop, 2002). In this extra-HPA role, CRF has been linked to stress (Dunn and Berridge, 1990), fear (Koob et al., 1993), and reward (Rivier and Vale, 1987). Antagonists of these peptides infused into the amygdala block consolidation of fear memory (Liang et al., 1992; Roozendaal et al., 2002). In general, activation of brain $\mathrm{CRF}_{1}$ is associated with anxiogenic behaviors (Liebsch et al., 1995), whereas activation of brain $\mathrm{CRF}_{2}$ may be involved in coping behavior in stressful situations (Liebsch et al., 1999). Radulovic et al. (1999) suggested that modulation by $\mathrm{CRF}_{1}$ versus $\mathrm{CRF}_{2}$ in learning and anxiety could be mediated by differential signaling.

Antagonism of $\mathrm{CRF}_{2}$ in the lateral septum or $\mathrm{CRF}_{1}$ in the amygdala reduces stress-induced behavior in the rat (Bakshi et al., 2002). Furthermore, Yadin et al. (1993) suggested that the LSMLN and the amygdala are critical nuclei in the expression and control of emotions, especially those involving fear, depression, anxiety, reward, and stress. These data support the hypothesis that the opposing actions of endogenous CRF-related peptides on their receptors in these two limbic nuclei may act in concert to regulate these plastic adaptations of the CNS. Altogether our data implicate a role for CRF-related peptides to modulate or perhaps regulate synaptic excitatory glutamatergic transmission locally under both normal and stressful conditions and emphasize that the effects of CRF-related peptides are dependent on multiple variables, including the brain area, the synapse, and sites within a given synapse.

In summary, we show a novel and highly crucial role for CRFrelated peptides as "modulators" of in vitro excitatory glutamatergic transmission in two limbic nuclei expressing their receptors. In this modulatory role, the receptors would function to establish a "tone" or homeostasis for normal excitatory glutamatergic transmission that is finely controlled by the endogenous levels of the peptides. CRF-receptor activation by CRF-related peptides could also serve as a priming (Blank et al., 2002) or metaplastic (Abraham and Bear, 1996) mechanism to provide additional modulation of excitatory transmission, when needed. The synaptic homeostasis of these endogenous CRF-related peptides and CRF receptors may also play an important role in initiating, expressing, or maintaining cellular signaling processes that contribute to learning, memory, anxiety, and depression. Finally, therapeutic agents interacting with CRF-related peptides could contribute to reestablishing synaptic homeostasis when perturbed during stress, e.g., at "stressed synapses," or in the induction of various mental illnesses associated with stress. 


\section{References}

Abraham WC, Bear MF (1996) Metaplasticity: the plasticity of synaptic plasticity. Trends Neurosci 19:126-130.

Aggleton JP (1992) The amygdala: neurobiological aspects of emotion, memory, and mental dysfunction. New York: Wiley.

Aldenhoff J, Gruol DL, Rivier J, Vale W, Siggins GR (1983) Corticotropin releasing factor decreases postburst hyperpolarizations and excites hippocampal neurons. Science 221:875-877.

Alheid GF, Heimer L (1988) New perspectives in basal forebrain organization of special relevance for neuropsychiatric disorders: the striatopallidal, amygdaloid, and corticopetal components of substantia innominata. Neuroscience 27:1-39.

Bakshi VP, Smith-Roe S, Newman SM, Grigoriadis DE, Kalin NH (2002) Reduction of stress-induced behavior by antagonism of corticotropinreleasing hormone 2 (CRH2) receptors in lateral septum or CRH1 receptors in amygdala. J Neurosci 22:2926-2935.

Bale TL, Vale WW (2004) CRF and CRF receptors: role in stress responsivity and other behaviors. Annu Rev Pharmacol Toxicol 44:525-557.

Bishop GA (2002) Development of a corticotropin-releasing factormediated effect on the firing rate of Purkinje cells in the postnatal mouse cerebellum. Exp Neurol 178:165-174.

Blank T, Nijholt I, Eckart K, Spiess J (2002) Priming of long-term potentiation in mouse hippocampus by corticotropin-releasing factor and acute stress: implications for hippocampus-dependent learning. J Neurosci 22:3788-3794.

Blank T, Nijholt I, Grammatopoulos DK, Randeva HS, Hillhouse EW, Spiess J (2003) Corticotropin-releasing factor receptors couple to multiple G-proteins to activate diverse intracellular signaling pathways in mouse hippocampus: role in neuronal excitability and associative learning. J Neurosci 23:700-707.

Bremner JD, Licinio J, Darnell A, Krystal JH, Owens MJ, Southwick SM, Nemeroff CB, Charney DS (1997) Elevated CSF corticotropin-releasing factor concentrations in posttraumatic stress disorder. Am J Psychiatry 154:624-629.

Chalmers DT, Lovenberg TW, De Souza EB (1995) Localization of novel corticotropin-releasing factor receptor (CRF2) mRNA expression to specific subcortical nuclei in rat brain: comparison with CRF1 receptor mRNA expression. J Neurosci 15:6340-6350.

Dallman MF (2003) Stress by any other name. . . ? Horm Behav 43:18-20.

Dautzenberg FM, Hauger RL (2002) The CRF peptide family and their receptors: yet more partners discovered. Trends Pharmacol Sci 23:71-77.

Dautzenberg FM, Killpatrick GJ, Hauger RL, Moreau J-L (2001) Molecular biology of the CRH receptors-in the mood. Peptides 22:753-760.

Dunn AJ, Berridge CW (1990) Physiological and behavioral responses to corticotropin-releasing factor administration: is CRF a mediator of anxiety in the stress response? Brain Res Rev 15:71-100.

Eaves M, Thatcher-Britton K, Rivier J, Vale W, Koob G (1985) Effects of corticotropin-releasing factor on locomotor activity in hypophysectomized rats. Peptides 6:923-926.

Fox EA, Gruol DL (1993) Corticotropin-releasing factor suppresses the afterhyperpolarization in cerebellar Purkinje neurons. Neurosci Lett 149:103-107.

Grammatopoulos DK, Randeva H, Levine M, Kanellopoulou K, Hillhouse E (2001) Rat cerebral cortex corticotropin-releasing hormone receptors: evidence for receptor coupling to multiple G-proteins. J Neurochem 76:509-519.

Harrigan EA, Magnuson DJ, Thunstedt GM, Gray TS (1994) Corticotropin releasing factor neurons are innervated by calcitonin gene-related peptide terminals in the rat central amygdaloid nucleus. Brain Res Bull 33:529-534.

Hauger RL, Grigoriadis DE, Dallman M, Plotsky PM, Vale WW, Dautzenberg FM (2003) International Union of Pharmacology. XXXVI. Current status of the nomenclature for receptors for corticotropin-releasing factor and their ligands. Pharmacol Rev 55:21-26.

Hsu SY, Hsueh AJW (2001) Human stresscopin and stresscopin-related peptide are selective ligands for the corticotropin-releasing hormone receptor. Nat Med 7:605-606.

Jakab RL, Leranth C (1995) Septum. In: The rat nervous system (Paxinos G, ed), pp 405-442. San Diego: Academic.

Katz B, Miledi R (1968) The role of calcium in neuromascular facilitation. J Physiol 195:481-492.

King JS, Bishop GA (2002) The distribution and cellular localization of
CRF-R1 in the vermis of the postnatal mouse cerebellum. Exp Neurol 178:175-185.

Koob GF, Heinrichs SC, Pich EM, Menzaghi F, Baldwin HA, Miczek KA, Britton KT (1993) The role of corticotropin-releasing factor in behavioural responses to stress. Ciba Found Symp 172:277-295.

Lewis K, Li C, Perrin MH, Blount A, Kunitake K, Donaldson C, Vaughan J, Reyes TM, Gulyas J, Fischer W, Bilezikjian L, Rivier J, Sawchenko PE, Vale WW (2001) Identification of urocortin III, an additional member of the corticotropin-releasing factor (CRF) family with high affinity for the CRF2 receptor. Proc Natl Acad Sci USA 98:7570-7575.

Li C, Vaughan J, Sawchenko PE, Vale WW (2002) Urocortin IIIimmunoreactive projections in rat brain: partial overlap with sites of type 2 corticotrophin-releasing factor receptor expression. J Neurosci 22:991-1001.

Liang KC, Melia KR, Campeau S, Falls WA, Miserendino MJ, Davis M (1992) Lesions of the central nucleus of the amygdala, but not the paraventricular nucleus of the hypothalamus, block the excitatory effects of corticotropin releasing factor on the acoustic startle reflex. J Neurosci 12:2313-2320.

Liebsch G, Landgraf R, Gerstberger R, Probst JC, Wotjak CT, Engelmann M, Holsboer F, Montkowski A (1995) Chronic infusion of a CRH1 receptor antisense oligodeoxynucleotide into the central nucleus of the amygdala reduced anxiety-related behavior in socially defeated rats. Regul Pept 59:229-239.

Liebsch G, Landgraf R, Engelmann M, Lorscher P, Holsboer F (1999) Differential behavioural effects of chronic infusion of CRH 1 and CRH 2 receptor antisense oligonucleotides into the rat brain. J Psychiatr Res 33:153-163.

Manabe T, Wyllie DJA, Perkel DJ, Nicoll RA (1993) Modulation of synaptic transmission and long-term potentiation: effects on paired pulse facilitation and EPSC variance in the CA1 region of the hippocampus. J Neurophysiol 70:1451-1459.

McCarthy JR, Heinrichs SC, Grigoriadis DE (1999) Recent advances with the CRF1 receptor design of small molecule inhibitors, receptor sybtypes and clinical implications. Curr Pharm Des 5:289-315.

McEwen BS, Wingfield JC (2003) The concept of allostasis in biology and biomedicine. Horm Behav 43:2-15.

Miyata M, Okada D, Hashimoto K, Kano M, Ito M (1999) Corticotropinreleasing factor plays a permissive role in cerebellar long-term depression. Neuron 22:763-775.

Müller MB, Zimmermann S, Sillaber I, Hagemeyer TP, Deussing JM, Timpl P, Kormann MS, Droste SK, Kuhn R, Reul JM, Holsboer F, Wurst W (2003) Limbic corticotropin-releasing hormone receptor I mediates anxiety-related behavior and hormonal adaptation to stress. Nat Neurosci 6:1100-1107

Neugebauer V, Zinebi F, Russell R, Gallagher JP, Shinnick-Gallagher P (2000) Cocaine and kindling alter the sensitivity of group II and III metabotropic glutamate receptors in the central amygdala. J Neurophysiol 84:759-770.

Numan R (2000) The behavioral neuroscience of the septal region. New York: Springer.

Owens MJ, Nemeroff CB (1993) The role of corticotropin-releasing factor in the pathophysiology of affective and anxiety disorders: laboratory and clinical studies. Ciba Found Symp 172:296-308.

Radulovic J, Ruhmann A, Liepold T, Spiess J (1999) Modulation of learning and anxiety by corticotropin-releasing factor (CRF) and stress: differential roles of CRF receptors 1 and 2. J Neurosci 19:5016-5025.

Rainnie DG, Fernhout BJH, Shinnick-Gallagher P (1992) Differential actions of corticotropin releasing factor on basolateral and central amygdaloid neurones, in vitro. J Pharmacol Exp Ther 263:846-858.

Reyes TM, Lewis K, Perrin MH, Kunitake KS, Vaughan J, Arias CA, Hogenesch JB, Gulyas J, Rivier J, Vale WW, Sawchenko PE (2001) Urocortin II: a member of the corticotropin-releasing factor (CRF) neuropeptide family that is selectively bound by type 2 CRF receptors. Proc Natl Acad Sci USA 98:2843-2848.

Rivier C, Vale W (1987) Cocaine stimulates adrenocorticotropin (ACTH) secretion through a corticotropin-releasing factor (CRF)-mediated mechanism. Brain Res 422:403-406.

Rivier J, Gulyas J, Kirby D, Low W, Perrin MH, Kunitake K, DiGruccio M, Vaughan J, Reubi J-C, Waser B, Koerber SC, Martinez V, Wang L, Tache Y, Vale W (2002) Potent and long-acting corticotropin releasing factor 
(CRF) receptor 2 peptide competitive antagonists. J Med Chem 45:4737-4747.

Rivier JE, Gulyas JD, Kirby K, Kunitake K, Donaldson C, Vaughn J, Perrin S, Koerber S, Martinez V, Tache Y, Rivier C, Vale W (2001) Receptorselective corticotropin-releasing factor analogs. Soc Neurosci Abstr 31:413.17.

Roozendaal B, Brunson KL, Holloway BL, McGaugh JL, Baram TZ (2002) Involvement of stress-released corticotropin-releasing hormone in the basolateral amygdala in regulating memory consolidation. Proc Natl Acad Sci USA 99:13908-13913.

Rothman RB, Vu N, Xu H, Baumann MH, Lu YF (2002) Endogenous corticotropin releasing factor regulates adrenergic and opioid receptors. Peptides 23:2177-2180.

Sauvage M, Steckler T (2001) Detection of corticotropin-releasing hormone receptor 1 immunoreactivity in cholinergic, dopaminergic and noradrenergic neurons of the murine basal forebrain and brainstem nuclei: potential implication for arousal and attention. Neuroscience 104:643-652.

Shinnick-Gallagher P, Pitkanen A, Shekhar A, Cahill L (2003) The amygdala in brain function: basic and clinical approaches. Ann NY Acad Sci 985.

Smith BN, Dudek FE (1994) Age-related epileptogenic effects of corticotropin-releasing hormone in the isolated CA1 region of rat hippocampal slices. J Neurophysiol 72:2328-2333.

Steckler T, Holsboer F (1999) Corticotropin-releasing hormone receptor subtypes and emotion. Biol Psychiatry 46:1480-1508.

Swanson LW, Sawchenko PE, Rivier J, Vale WW (1983) Organization of ovine corticotropin-releasing factor immunoreactive cells and fibers in the rat brain: an immunohistochemical study. Neuroendocrinology 36:165-186.

Ungless MA, Singh V, Crowder TL, Yaka R, Ron D, Bonci A (2003) Corticotropin-releasing factor requires $\mathrm{CRF}$ binding protein to potentiate NMDA receptors via CRF receptor 2 in dopamine neurons. Neuron 39:401-407.
Vale W, Spiess J, Rivier C, Rivier J (1981) Characterization of a 41-residue ovine hypothalamic peptide that stimulates secretion of corticotropin and beta-endorphin. Science 213:1394-1397.

Valentino RJ (1989) Corticotropin-releasing factor: putative neurotransmitter in the noradrenergic nucleus locus ceruleus. Psychopharmacol Bull 25:306-311.

Vaughan J, Donaldson C, Bittencourt J, Perrin MH, Lewis K, Sutton S, Chan R, Turnbull AV, Lovejoy D, Rivier C (1995) Urocortin, a mammalian neuropeptide related to fish urotensin I and to corticotropin-releasing factor. Nature 378:287-292.

Vythilingam M, Anderson GM, Owens MJ, Halaszynski TM, Bremner JD, Carpenter LL, Heninger GR, Nemeroff CB, Charney DS (2000) Cerebrospinal fluid corticotropin-releasing hormone in healthy humans: effects of yohimbine and naloxone. $J$ Clin Endocrinol Metab 85:4138-4145.

Wang HL, Tsai LY, Lee EHY (2000) Corticotropin-releasing factor produces a protein synthesis-dependent long-lasting potentiation in dentate gyrus neurons. J Neurophysiol 83:343-349.

Webster EL, Lewis DB, Torpy DJ, Zachman EK, Rice KC, Chrousos GP (1996) In vivo and in vitro characterization of antalarmin, a nonpeptide corticotripin-releasing hormone $(\mathrm{CRH})$ receptor antagonist: suppression of pituitary ACTH release and peripheral inflammation. Endocrinology 137:5747-5750.

Yadin E, Thomas E, Grishkat HL, Strickland CE (1993) The role of the lateral septum in anxiolysis. Physiol Behav 53:1077-1083.

Yu B, Shinnick-Gallagher P (1998) Corticotropin-releasing factor increases dihydropyridine- and neurotoxin-resistant calcium currents in neurons of the central amygdala. J Pharmacol Exp Ther 284:170-179.

Yu B, Wang C, Liu J, Johnson KM, Gallagher JP (2002) Adaptation to chronic PCP results in hyperfunctional NMDA and hypofunctional $\mathrm{GABA}_{\mathrm{A}}$ synaptic receptors. Neuroscience 113:1-10. 